\title{
Analisis Deiksis Dialek Kulisusu Masyarakat Desa Rante Gola Kecamatan Bonegunu Kabupaten Buton Utara
}

\author{
Tofan Stofiana \\ Universitas Muhammadiyah Buton \\ E-mail: tofanstofiana@gmail.com
}

\begin{abstract}
This study aims to find out whether the sort card media can improve speaking skills in learning to tell the experience of students of class X-3 of SMAN 2 Lasalimu Selatan. This research was compiled based on the Classroom Action Research (CAR) design which was divided into two cycles with four stages per cycle, namely planning, action, observation and reflection. The first cycle was held from 9 to 14 January 2017. The second cycle was held on January 16 to 212017 in class X-2 of SMAN 2 Lasalimu Selatan. The results of the study show that the use of sort card media increases speaking skills in learning to tell the experience of X-3 grade students of SMAN 2 Lasalimu Selatan. This increase is indicated by the acquisition of success percentage of $67.44 \%$ in the first cycle and increased by $5.36 \%$ in the second cycle to reach the success percentage of $76.33 \%$
\end{abstract}

Keywords: Speaking Skills, Storytelling Learning Experiences, Media Sort Cards

\begin{abstract}
Abstrak
Penelitian ini bertujuan untuk mngetahui apakah media sortir kartu (sort card) dapat meningkatkan kemampuan berbicara pada pembelajaran bercerita pengalaman siswa kelas X-3 SMAN 2 Lasalimu Selatan. Penelitian ini disusun berdasarkan rancangan Penelitian Tindakan Kelas (PTK) yang terbagi atas dua siklus dengan empat tahap per siklusnya, yakni perencanaan, tindakan, observasi dan refleksi. Siklus pertama dilaksanakan mulai tanggal 9 hingga 14 Januari 2017. Siklus ke dua dilaksanakan pada tanggal 16 hingga 21 Januari 2017 di kelas X-2 SMAN 2 Lasalimu Selatan. Hasil penelitian menunjukan bahwa penggunaan media sortir kartu (sort card) meningkatan kemampuan berbicara pada pembelajaran bercerita pengalaman siswa kelas X-3 SMAN 2 Lasalimu Selatan. Peningkatan ini ditunjukkan dengan perolehan presentase keberhasilan sebesar 67,44\% pada siklus pertama dan bertambah 5,36\% pada siklus kedua hingga mencapai presentase keberhasilan 76,33\%.
\end{abstract}

Kata kunci: Keterampilan Berbicara, Pembelajaran Bercerita Pengalaman, Media Sortir Kartu.

\section{PENDAHULUAN}

Ada dua faktor yang menyebabkan rendahnya tingkat kemampuan siswa dalam berbicara, yaitu faktor eksternal dan faktor internal. Faktor eksternal penyebab rendahnya tingkat kemampuan berbicara adalah pengaruh penggunaan bahasa Indonesia di lingkungan keluarga dan masyarakat. Dalam proses komunikasi sehari-hari, banyak keluarga yang menggunakan bahasa ibu (bahasa daerah) sebagai bahasa percakapan di lingkungan keluarga. Demikian juga halnya dengan penggunaan bahasa Indonesia di tengah-tengah masyarakat. Rerata bahasa ibulah yang digunakan sebagai sarana komunikasi. Kalau ada tokoh masyarakat yang menggunakan bahasa Indonesia, pada umumnya belum memerhatikan kaidah-kaidah berbahasa secara baik dan benar. Akibatnya, siswa tidak terbiasa untuk berbahasa Indonesia sesuai dengan konteks dan situasi tutur.

Dari faktor internal, pendekatan pembelajaran, penerapan media, media, atau sumber pembelajaran yang digunakan oleh guru memiliki pengaruh yang cukup signifikan terhadap tingkat kemampuan berbicara bagi siswa SMA. Pada umumnya, guru bahasa Indonesia cenderung menggunakan pendekatan yang konvensional dan miskin inovasi sehingga kegiatan pembelajaran kemampuan berbicara berlangsung monoton dan membosankan.

Jika kondisi pembelajaran semacam itu dibiarkan berlarut-larut, bukan tidak mungkin kemampuan berbicara di kalangan siswa SMA akan terus berada pada taraf yang rendah. Dalam konteks demikian, diperlukan pendekatan 
pembelajaran kemampuan berbicara yang inovatif dan kreatif, sehingga proses pembelajaran bisa berlangsung aktif, efektif, dan menyenangkan. Siswa tidak hanya diajak untuk belajar tentang bahasa secara rasional dan kognitif, tetapi juga diajak untuk belajar dan berlatih dalam konteks dan situasi tutur yang sesungguhnya dalam suasana yang dialogis, interaktif, menarik, dan menyenangkan. Dengan cara demikian, siswa tidak akan terpasung dalam suasana pembelajaran yang kaku, monoton, dan membosankan. Pembelajaran kemampuan berbicarapun menjadi sajian materi yang selalu dirindukan dan dinantikan oleh siswa.

Pada penelitian ini, peneliti akan menerapkan sebuah media pembelajaran yang menggunakan kartu dengan penerapannya adalah disortir. Sortir kartu (sort card) merupakan strategi pembelajaran berupa potongan-potongan kertas yang dibentuk seperti kartu yang berisi informasi atau materi pelajaran. Pembelajaran aktif menggunakan media sortir kartu (sort card) merupakan pembelajaran yang menekankan keaktifan siswa, dimana dalam pembelajaran ini setiap siswa diberi kartu indeks yang berisi informasi tentang materi (tema) yang akan dibahas, dan seorang siswa dituntut harus bisa untuk bisa menyampaikan pokok atau tema yang diberikan kepadanya untuk teman-temannya di depan kelas. Di sini pendidik lebih banyak bertindak sebagai fasilitator dan menjelaskan materi yang perlu dibahas atau materi yang belum dimengerti siswa setelah persentase selesai.

Mengenai pembelajarana yang akan ditingkatkan menggunakan media sortir kartu (sort card) ini adalah bercerita pengalaman. Di sini ada kaitan yang sangat erat antara bercerita dan berbicara karena seseorang bercerita berarti dia sedang berbicara. Sesuai dengan silabus pembelajaran kurikulum tingkat satuan pendidikan materi ini berada di pembelajaran kelas X. oleh sebab itu, peneliti akan menjadikan kelas X-3 sebagai subjek penelitian dalam penelitian ini. Untuk sekolah yang dijadikan sebagai tempat penelitian ini adalah SMAN 2 Lasalimu Selatan. Peneliti sangat tertarik untuk melakukan penelitian di sekolah ini karena berdasarkan pengalaman peneliti ketika melakukan observasi sebelum menyusun rencana, peneliti telah mendapatkan informasi dari guru bidang studi bahasa Indonesia bahwa kelas X-3 memiliki kemampuan yang rendah dalam kemampuan berbicara. Hal ini juga dibuktikan oleh peneliti ketika berkolaborasi dengan guru bidang studi bahasa Indonesia dalam mengajar, kelas ini terbilang pasif ketika disajikan masalah.

Berdasarkan hal-hal di atas, maka peneliti memutuskan untuk mengadakan sebuah penelitian dengan judul "Peningkatan Kemampuan Berbicara pada Pembelajaran Bercerita Pengalaman Menggunakan Media Sortir kartu (sort card) pada Siswa Kelas X-3 SMA Negeri 2 Lasalimu Selatan"

Sementara tujuan tujuan yang ingin dicapai dalam penelitian ini adalah untuk mengetahui peningkatan kemampuan berbicara pada pembelajaran bercerita pengalaman meggunakan media sortir kartu (sort card) pada siswa Kelas X3 SMA Negeri 2 Lasalimu Selatan.

\section{METODE}

Penelitian ini adalah penelitian tindakan kelas (classroom action research). Pengategorian penelitian ini ke dalam penelitian tindakan sesuai dengan model Kemmis dan Mc. Taggart. Dalam perencanaanya, Kemmis menggunakan sistem spiral refleksi diri yang dimulai dengan rencana, tindakan, pengamatan, refleksi dan perencanaan kembali yang merupakan dasar untuk suatu ancang-ancang pemecahan masalah (Sukkidin dkk, 2012:48)

Penelitian ini berlokasi di SMAN 2 Lasalimu Selatan. Waktu yang akan dibutuhkan dalam penelitian ini adalah lebih kurang satu bulan waktu mengajar. Penelitian ini akan dilakukan pada semester pertama tahun ajaran 2017/2018 .

Sesuai dengan silabus pembelajaran, materi bercerita pengalaman terdapat pada silabus kelas $\mathrm{X}$ semester pertama. Sesuai hal ini, maka peneliti menjadikan kelas X-3 sebagai subjek dalam penelitian ini. Kelas X-3 memiliki siswa sebanyak 25 siswa, terdiri atas 13 siswa laki-laki dan sisanya yakni 12 siswa berjenis kelamin perempuan.

Penelitian tindakan kelas ini dilakukan dalam dua siklus. Pada tiap siklus terdiri dari empat tahap, yaitu perencanaan, tindakan, observasi, dan refleksi. Siklus I bertujuan untuk mengetahui ampuhnya penerapan media sortir kartu (sort card) dalam pembelajaran bercerita pengalaman untuk meningkatkan kemampuan berbicara siswa, kemudian hasil dari siklus I digunakan sebagai refleksi untuk melakukan siklus II. Siklus II bertujuan untuk mengetahui keberhalisan penerapan media sortir kartu (sort card) pada pembelajaran bercerita dalam meningkatkan kemampuan berbicara siswa. 
Dalam penelitian ini peneliti menggunakan dua cara atau teknik dalam mengumpulkan data antara lain:

\section{Teknik Tes}

Tes yang digunakan untuk mengukur kemampuan berbicara adalah tes performen bercerita yaitu menugasi siswa untuk praktik cerita dengan membawakan tema yang telah didapatkan melalui penerapan media sortir kartu (sort card). Tes ini digunakan untuk mengetahui tingkat kemampuan berbicara siswa kelas X-3 SMAN 2 Lasalimu Selatan. Adapun instrumen yang digunakan pada teknik ini adalah lembar tes performen dengan format dibawah ini.

Tabel 3.1 Instrumen Penilaian Kemampuan Bercerita Pengalaman

\begin{tabular}{|c|l|c|c|c|c|c|}
\hline \multirow{2}{*}{ No } & \multicolumn{2}{|c|}{ Aspek yang dinilai } & \multicolumn{5}{|c|}{ Skor } \\
\cline { 3 - 7 } & & $\mathbf{1}$ & $\mathbf{2}$ & $\mathbf{3}$ & $\mathbf{4}$ & $\mathbf{5}$ \\
\hline 1. & Pelafalan & & & & & \\
\hline 2. & $\begin{array}{l}\text { Penempatan tekanan dan } \\
\text { nada }\end{array}$ & & & & & \\
\hline 3. & Penilaian kata (diksi) & & & & & \\
\hline 4. & Ekspresi & & & & & \\
\hline 5. & Kelancaran & & & & & \\
\hline 6. & Penegasan cerita & & & & & \\
\hline & Jumlah skor & \multicolumn{5}{|c|}{} \\
\hline
\end{tabular}

\section{Keterangan:}
5 : Sangat baik
2 : Kurang
4 : Baik
3 : Cukup
1 : Sangat kurang

\section{Teknik Observasi}

Observasi digunakan untuk mendapatkan data tentang situasi kegiatan belajar mengajar di kelas, dan kesulitan-kesulitan siswa dalam ketrampilan berbicara. Teknik observasi yang digunkan peneliti adalah observasi siswa.

Pedoman observasi yang digunakan dalam penelitian ini adalah lembar pengamatan untuk siswa. Dengan observasi seluruh aktivitas siswa selama proses pembelajaran akan terpotret. Dalam penelitian ini observasi digunakan untuk mengumpulkan data tentang siswa dalam kegiatan belajar mengajar. Lembar pengamatan digunakan untuk mendapat data tentang perilaku dan respon siswa selama proses pembelajaran berlangsung pada siklus I dan sisklus II. Observasi yang digunakan adalah proses sistematis karena mengandalkan penggunaan kategori-kategori yang relatif rinci, sehingga perekaman datanya hanya berupa pengisian daftar cocok (check list).

Data yang diperoleh pada penelitian ini akan dianalisis dengan teknik kuantitatif. Adapun langkah-langkah dalam teknik analisis ini adalah:

1. Merekap skor yang telah diperoleh siswa pada tiap siklusnya;

2. Skor yang diperoleh diubah dalam bentuk nilai akhir siswa dengan rumus sebagai berikut.

\section{Nilai akhir siswa $=\underline{\text { jumlah nilai seluruh aspek }} \times 100$ Jumlah skor maksimal}

Adapun kategori dan rentang nilai berdasarkan nilai akhir siswa adalah sebagai berikut:

Tabel 3.2 Rentang Skor Dan Kategori

\begin{tabular}{|c|l|c|}
\hline No & Katagori & Rentang Nilai \\
\hline 1 & Sangat baik & $86-100$ \\
\hline 2 & Baik & $70-85$ \\
\hline 3 & Cukup baik & $60-69$ \\
\hline 4 & Kurang baik & $<59$ \\
\hline
\end{tabular}

3. Untuk mengetahui rerata dapat menggunakan rumus berikut.

\section{Nilai rerata $=$ jumlah nilai seluruh siswa jumlah siswa}

4. Nilai hasil dari tiap-tiap tes itu kemudian dikumpulkan dan dianalisis untuk mengetahui persentase keberhasilan, dengan menggunakan rumus sebagai berikut:

$$
\mathrm{NP}=\frac{\sum \mathrm{n}}{\mathrm{N} \times \mathrm{S}} \times 100 \%
$$

\section{Keterangan:}

$\mathrm{NP}$ : nilai presentase kemampuan siswa

$\sum \mathrm{n} \quad$ : jumlah nilai dalam satu kelas

$\mathrm{N}$ : nilai maksimal

S : jumlah responden dalam satu kelas

Hasil dari perhitungan tersebut kemudian dikumpulkan dan dibandingkan antara siklus I dan siklus II. Hasil perbandingan itulah yang kemudian memberikan gambaran sekaligus menentukan seberapa besar peningkatan kemampuan bercerita dengan menggunakan media sortir kartu (sort card). 


\section{HASIL DAN PEMBAHASAN}

\section{Siklus I}

a. Proses Pembelajaran

1) Pertemuan Pertama

Pada pertemuan pertama, pelaksanaan tindakan berlangsung selama $2 \times 45$ menit dan dilaksanakan pada hari Rabu, 11 Januari pukul 09.15 WITA di kelas X-3 SMAN 2 Lasalimu Selatan. Pada pertemuan ini peneliti belum menyortir kartu karena peneliti masih harus mengapersepsi kembali materi pembelajaran mengenai bercerita pengalaman. Pada pertemuan ini peneliti juga mencontohkan bagaimana cara bercerita pengalaman yang baik sesuai dengan indikator penilaian.

Adapun langkah-langkah pembelajaran pada pertemuan ini adalah:

a) Peneliti membuka pelajaran (apersensi dan presensi);

b) Peneliti menjelaskan tentang tujuan pembelajaran kemampuan bercerita pengalaman;

c) Peneliti menjelaskan alur kegiatan yang akan dijalankan bersama-sama;

d) Peneliti menjelaskan materi bercerita pengalaman;

e) Peneliti memberikan kesempatan kepada siswa yang bertanya dan R17, R6, R7 dan R13 mengajukan pertanyaan;

f) Peneliti menceritakan sebuah pengalaman dengan memenuhi kriteria penilaian sebagai contoh dari cerita pengalaman yang baik;

g) Peneliti memberikan kesempatan pada siswa yang hendak mencoba menceritakan pengalamannya sebagai bentuk latihan dan siswa R17 dan R13 menggunakan kesempatan ini;

h) Peneliti mengevaluasi penampilan R17 dan R13 agar menjadi refleksi bagi seluruh siswa;

i) Peneliti menyampaikan rencana pembelajaran pada pertemuan berikutnya;

j) Pelajaran diakhiri dengan berdoa dan salam.

\section{2) Pertemuan Kedua}

Pertemuan kedua ini dilaksnakan pada hari kamis, tanggal 12 Januari 2017 dimulai jam 07.30
WITA di kelas X-3 SMAN 2 Lasalimu Selatan dan berlangsung selama 2 X45 menit. Pada pertemuan kali ini, peneliti sudah menggunakan media sortir kartu (sort card). Kartu-kartu yang disortir itu berisi pokok-pokok cerita yang akan dikembangkan oleh siswa secara individu sesuai dengan tema yang diperoleh. Adapun tema yang digunakan pada pertemuan ini adalah "pengalaman di sekolah". Dengan tema "pengalaman di sekolah" peneliti membaginya lagi dalam 6 bagian sehingga cerita menjadi variatif. Adapun bagian-bagian tersebut adalah:

a) Pengalaman yang memalukan di sekolah;

b) Pengalaman yang menjengkelkan di sekolah;

c) Pengalaman yang membahagiakan di sekolah;

d) Pengalaman yang menyedihkan di sekolah;

e) Pengalaman yang lucu di sekolah;

f) Pengalaman pertama masuk sekolah.

Pertemuan kedua ini juga menjadi evaluasi dari ujicoba penggunaan media sortir kartu (sort card) di siklus pertama. Adapun langkah-langkah yang dilakukan peneliti pada pertemuan ini adalah:

a) Peneliti membuka pelajaran (apersensi dan presensi);

b) Peneliti menjelaskan alur kegiatan yang akan dijalankan bersama-sama;

c) Peneliti menyortir kartu yang berisikan pokok-pokok cerita dengan tema utama "pengalaman di sekolah" dengan subtema yang berbeda-beda;

d) Peneliti menginstruksikan setiap siswa untuk mencari teman yang mendapatkan subtema yang sama;

e) Peneliti memberikan waktu 5 menit agar siswa berdiskusi tentang pengalaman yang akan diceritakan;

f) Peneliti meminta siswa secara bergantian untuk menceritakan pengalaman yang telah mereka siapkan;

g) Pelajaran diakhiri dengan berdoa dan salam.

\section{b. Hasil Kemampuan Bercerita Pengalaman Siklus I}

Hasil bercerita pengalaman pada tahap siklus I akan digambarkan pada tabel berikut ini. 
Tabel 4.1 Hasil Bercerita Pengalaman Siklus I

\begin{tabular}{|c|c|c|c|c|}
\hline Resp & $\begin{array}{c}\text { Total } \\
\text { Skor }\end{array}$ & $\begin{array}{c}\text { NILAI AKHIR } \\
\text { jumlah nilai seluruh aspek X 100 } \\
\text { Jumlah skor maksimal }\end{array}$ & Kat & Ket \\
\hline R1 & 22 & 73 & B & \\
\hline R2 & 21 & 70 & B & \\
\hline R3 & - & - & - & Tidak hadir \\
\hline R4 & 19 & 63 & C & \\
\hline R5 & 19 & 63 & C & \\
\hline R6 & 24 & 80 & B & \\
\hline R6 & 23 & 77 & B & \\
\hline R8 & 22 & 73 & B & \\
\hline R9 & 23 & 77 & B & \\
\hline R10 & 19 & 63 & C & \\
\hline R11 & 23 & 77 & B & \\
\hline R12 & 20 & 67 & C & \\
\hline R13 & 23 & 77 & B & \\
\hline R14 & - & - & - & Tidak hadir \\
\hline R15 & 19 & 63 & C & \\
\hline R16 & 19 & 63 & C & \\
\hline R17 & 26 & 87 & SB & \\
\hline R18 & 19 & 63 & C & \\
\hline R19 & 20 & 67 & C & \\
\hline R20 & 19 & 63 & C & \\
\hline R21 & 24 & 80 & B & \\
\hline R22 & 22 & 73 & B & \\
\hline R23 & 18 & 60 & C & \\
\hline R24 & 21 & 70 & B & \\
\hline R25 & 21 & 70 & & \\
\hline & & & B & \\
\hline
\end{tabular}

Berdasarkan hasil yang telah dipaparkan, maka akan dihitung persentase keberhasihan pada tabel rentang nilai di bawah ini.

Tabel 4.2 Rentang Nilai dan Keberhasilan Siklus I

\begin{tabular}{|c|c|c|c|c|c|}
\hline Kat & $\begin{array}{c}\text { Rentang } \\
\text { Nilai }\end{array}$ & Frekuensi & $\begin{array}{l}\text { Bobot } \\
\text { Skor }\end{array}$ & Persen $(\%)$ & $\begin{array}{c}\text { Persentase } \\
\text { Keberhasilan }\end{array}$ \\
\hline \multirow{2}{*}{ Sangat baik } & \multirow{2}{*}{$86-100$} & \multirow{2}{*}{1} & \multirow{2}{*}{87} & \multirow{2}{*}{$4 \%$} & $\sum \mathrm{n}$ \\
\hline & & & & & NX S \\
\hline Baik & $70-85$ & 12 & 897 & $48 \%$ & 1.686 \\
\hline Cukup & $60-69$ & 10 & 702 & $40 \%$ & 2.500 \\
\hline Kurang & $0-59$ & - & - & - & $=67,44 \%$ \\
\hline \multicolumn{2}{|c|}{ Jumlah } & 23 & 1.686 & $92 \%$ & \\
\hline \multicolumn{2}{|c|}{ Keterangan } & \multicolumn{4}{|c|}{$2(8 \%)$ responden tidak hadir } \\
\hline
\end{tabular}


Berdasarkan data pada tabel 4.2 dapat dinyatakan bahwa hasil tes kemampuan bercerita pengalaman pada siklus I siswa kelas X-3 SMAN 2 Lasalimu Selatan, mencapai total nilai 1.686, dengan persentase $67,44 \%$ yang telah memenuhi persentase keberhasilan di siklus I. Dari jumlah responden 25 siswa terdapat 1 (4\%) siswa yang berhasil memperoleh nilai dengan kategori sangat baik dengan rentang nilai 86-100. Selanjutnya siswa yang memperoleh nilai dengan kategori baik terdapat $12(48 \%)$ dengan rentang nilai 70-85, siswa yang memperoleh nilai dengan kategori cukup terdapat $10(40 \%)$ siswa dengan rentang nilai 60-69. Terdapat bahwa $2(8 \%)$ siswa tidak hadir pada pertemuan ini.

Nilai siklus I diperoleh dari penjumlahan skor masing-masing aspek, yaitu pelafalan, intonasi, diksi, ekspresi, kelancaran, dan penegasan cerita. Hasil perolehan nilai untuk masing-masing aspek penilaian bercerita pengalaman menggunakan media sortir kartu (sort card) tercantum dalam tabel-tabel berikut.

Tabel 4.3 Pencapaian Aspek Pelafalan

Siklus I

\begin{tabular}{|c|c|c|c|l|c|}
\hline No & Skor & Frekuensi & Bobot Skor & Persentase Keberhasilan & Nilai Rerata \\
\hline 1 & 5 & 0 & 0 & $\frac{\sum \mathrm{n}}{\mathrm{X}} \mathrm{X} 100 \% \mathrm{NXS}$ & $\frac{77}{25}$ \\
2 & 4 & 5 & 20 & 77 & $\begin{array}{c}\text { Kategori cukup } \\
3\end{array}$ \\
3 & 18 & 57 & $\frac{125}{125} \mathrm{X} 100 \%$ & \\
4 & 2 & 0 & 0 & & \\
5 & 1 & 0 & 0 & & \\
\hline
\end{tabular}

Berdasarkan tabel 4.3 dinyatakan bahwa pelafalan siswa kelas X-3 SMAN 2 Lasalimu Selatan saat bercerita mencapai skor rerata 3,08 atau dengan persentase $61,6 \%$. Hal tersebut menandakan bahwa pelafalan siswa saat bercerita masih dikategorikan cukup. Cukupnya pelafalan siswa saat bercerita disebabkan karena kelas ini termasuk kelas dengan siswa multilingual. Ketika bercerita siswa yang bersuku Bali agak kesulitan mengucapkan huruf ' $t$ ', hal ini dialami oleh siswa $\mathrm{R} 11$, dan beberapa siswa yang bersuku Jawa sangat sulit melafalkan dengan ringan kata-kata yang memilki huruf ' $b$ ', dan ' $d$ ', lain halnya dengan siswa yang bersuku Ciacia sangat tebal ketika menlafalkan kata yang memiliki huruf ' $w$ '.

Tabel 4.4 Pencapaian Aspek Intonasi Siklus I

\begin{tabular}{|c|c|c|c|l|c|}
\hline No & Skor & Frekuensi & Bobot Skor & Persentase Keberhasilan & Nilai rerata \\
\hline 1 & 5 & 0 & 0 & $\sum \mathrm{n}$ & $\frac{81}{25}$ \\
2 & 4 & 12 & 48 & 81 & $=64,8 \%$ \\
3 & 3 & 11 & 33 & $\frac{81}{125}$ X100\% & $\begin{array}{c}\text { Kategori } \\
\text { cukup }\end{array}$ \\
4 & 2 & 0 & 0 & & \\
5 & 1 & 0 & 0 & & \\
\hline
\end{tabular}


Berdasarkan tabel 4.4 dinyatakan bahwa intonasi siswa kelas X-3 SMAN 2 Lasalimu Selatan saat bercerita mencapai skor rerata 3,24 atau dengan persentase $61,6 \%$. Hal tersebut menandakan bahwa intonasi siswa saat bercerita masih dikategorikan cukup. Beberapa alasan penyebab kurangnya keberhasilan pada aspek ini adalah beberapa siswa yang masih kelihatan grogi ketika bercerita sehingga nada dan suara yang dikelaurkan datar-datar saja. Hal lain penyebab cukupnya aspek intonasi adalah rasa malu, ada beberapa siswa yang ketika bercerita hanya menunduk dan tidak menikmati cerita yang ia bawakan.

Tabel 4.5 Pecapaian Aspek Diksi Siklus I

\begin{tabular}{|c|c|c|c|c|c|}
\hline No & Skor & Frekuensi & Bobot skor & Persentase Keberhasilan & Nilai Rerata \\
\hline 1 & 5 & 0 & 0 & $\sum \mathrm{n}$ & $\frac{78}{25}$ \\
\hline 2 & 4 & 9 & 36 & (n) & \\
\hline 3 & 3 & 14 & 42 & $\frac{78}{} \times 100 \%$ & $\begin{array}{c}=3,12 \\
\text { Kategori cukup }\end{array}$ \\
\hline 4 & 2 & 0 & 0 & 125 & \\
\hline 5 & 1 & 0 & 0 & & \\
\hline \multicolumn{2}{|c|}{ Jumlah } & 23 & 78 & & \\
\hline
\end{tabular}

Berdasarkan tabel 4.5 dinyatakan bahwa diksi siswa kelas X-3 SMAN 2 Lasalimu Selatan saat bercerita mencapai skor rerata 3,12 atau dengan persentase $62,4 \%$. Hal tersebut menandakan bahwa diksi siswa saat bercerita masih dikategorikan cukup. Alasan utama penyebab cukupnya aspek diksi ini karena tidak terbiasanya siswa dalam berbicara. Hal ini dapat dilihat dari beberapa dari 25 siswa ini ketika berbicara masih mencampurkode dengan bahasa sehari-hari. Diksi yang dipilih ketika bercerita bukanlah bahasa yang baku. Seseorang ketika terbiasa berbicara di depan forum akan mempunyai kenbiasaan menyampaikan kalimat dengan terstruktur dan dengan pilihan kata yang baik.

Tabel 4.6 Pencapian Aspek Ekspresi Siklus I

\begin{tabular}{|c|c|c|c|c|c|}
\hline No & Skor & Frekuensi & Bobot Skor & Persentase Keberhasilan & Nilai Rerata \\
\hline 1 & 5 & 0 & 0 & $\sum^{\sum \mathrm{n}} \times 100 \% \mathrm{NXS}$ & $\frac{81}{25}$ \\
\hline 2 & 4 & 12 & 48 & & \\
\hline 3 & 3 & 11 & 33 & ${ }^{81} \times 100 \%$ & $\begin{array}{c}=3,24 \\
\text { Kategori cukup }\end{array}$ \\
\hline 4 & 2 & 0 & 0 & 125 & \\
\hline 5 & 1 & 0 & 0 & & \\
\hline \multicolumn{2}{|c|}{ Jumlah } & 23 & 81 & & \\
\hline
\end{tabular}


Berdasarkan tabel 4.6 dinyatakan bahwa ekspresi siswa kelas X-3 SMAN 2 Lasalimu Selatan saat bercerita mencapai skor rerata 3,24 atau dengan persentase $61,6 \%$. Hal tersebut menandakan bahwa ekspresi siswa saat bercerita masih dikategorikan cukup. Peneliti dapat menyimpulkan bahwa ekspresi berjalan searah dengan intonasi. Ketika seroang siswa menyampaikan sebuah cerita dengan intonasi yang baik, maka siswa tersebut mampu pula untuk berekspresi mengikuti intonasi itu. Lagi-lagi grogi dan malu yang menjadi penyebab utama cukupnya aspek ini. Banyak siswa yang grogi ketika bercerita sehingga ia tidak bisa berekspresi dan beberapa siswa harus tunduk karena malu sehingga ekspresi wajah tidak diperlihatkan dengan kata lain ia tidak berekspresi.

Tabel 4.7 Pencapaian Aspek Kelancaran

Siklus I

\begin{tabular}{|c|c|c|c|c|c|}
\hline No & Skor & Frekuensi & Bobot Skor & Persentase Keberhasilan & Nilai rerata \\
\hline 1 & 5 & 1 & 5 & $\stackrel{\sum \mathrm{n}}{ } \times 100 \% \mathrm{NXS}$ & $\frac{80}{25}$ \\
\hline 2 & 4 & 9 & 36 & & \\
\hline 3 & 3 & 13 & 39 & $\frac{80}{125} X 100 \%$ & $\begin{array}{c}=3,2 \\
\text { Kategori cukup }\end{array}$ \\
\hline 4 & 2 & 0 & 0 & $=64 \%$ & \\
\hline 5 & 1 & 0 & 0 & & \\
\hline \multicolumn{2}{|c|}{ Jumlah } & 23 & 80 & & \\
\hline
\end{tabular}

Berdasarkan tabel 4.7 dinyatakan bahwa kelancaran siswa kelas X-3 SMAN 2 Lasalimu Selatan saat bercerita mencapai skor rerata 3,2 atau dengan persentase $64 \%$. Hal tersebut menandakan bahwa kelancaran siswa saat bercerita masih dikategorikan cukup. Salah satu alasan yang paling mendasar dalam hal ini adalah tidak adanya konsep cerita yang dibuat lebih awal. Siswa hanya mengingat apa yang pernah dialaminya dan langsung diceritakan. Banyak siswa yang terbata-bata ketika bercerita dan harus mengulang beberapa bagian dengan sikap ragu-ragu.

Tabel 4.8 Pencapaian Aspek Penegasan Cerita Siklus I

\begin{tabular}{|c|c|c|c|l|c|}
\hline No & Skor & Frekuensi & Bobot skor & Persentase keberhasilan & Nilai rerata \\
\hline 1 & 5 & 2 & 10 & $\frac{\sum \mathrm{n}}{-X 100 \% \mathrm{NXS}}$ & $\frac{91}{25}$ \\
2 & 4 & 18 & 72 & & $=3,64$ \\
3 & 3 & 3 & 9 & $\frac{91}{125} \mathrm{X} 100 \%$ & Kategori cukup \\
4 & 2 & 0 & 0 & 0 & \\
5 & 1 & 0 & 0 & & \\
\hline \multicolumn{2}{|l|}{ Jumlah } & $\mathbf{2 3}$ & $\mathbf{9 1}$ & & \\
\hline
\end{tabular}


Berdasarkan tabel 4.8 terdapat bahwa penegasan cerita siswa kelas X-3 SMAN 2 Lasalimu Selatan saat bercerita mencapai skor rerata 3,64 atau dengan persentase $72,8 \%$. Hal tersebut menandakan bahwa penegasan cerita saat bercerita masih dikategorikan cukup. Sebenarnya pada aspek ini tidak memiliki hambatan karena tema yang menjadi hal tersulit dalam menciptakan sebuah cerita telah ditentukan dengan menggunakan media sortir kartu (sort card). Siswa hanya mengembangkan sesuai tema tersebut sehingga cerita menjadi tegas. Dapat dilihat ada 2 siswa yang memang memiliki kategori yang sangat baik, namun masih ada juga siswa yang mendapatkan kategori yang cukup. Penyebab hal ini dapat terjadi masih berhubungan dengan kelancaran yakni karena tidak adanya konsep. Mereka hanya bercerita semau yang mereka tahu tanpa disadari terkadang apa yang dicertiakan menjadi tidak jelas.

\section{c. Observasi Siklus I}

Pengambilan data melalui observasi bertujuan untuk mendapatkan informasi tentang perilaku siswa selama proses pembelajaran. Aspek yang diamati dalam observasi adalah perilaku positif siswa yang ditunjukan selama proses pembelajaran berlangsung. Aspek yang menjadi sasaran observasi adalah antusias siswa memperhatikan penjelasan peneliti, antusias siswa untuk bertanya dan berkomentar, antusias dan keberanian siswa untuk bercerita di depan kelas, hubungan antar teman serta sikap terhadap guru dalam hal ini adalah peneliti.

Siklus I seluruh perilaku siswa selama proses pembelajaran terdeskripsi melalui lembar observasi. Selama proses pembelajaran berlangsung, tidak semua siswa tertib mengikuti pembelajaran, ada siswa yang belum siap belajar terlihat mengobrol dengan temannya, adapula siswa yang masih terlihat bingung. Namun hal tersebut bukan menjadi sebuah masalah, karena merupakan tahap awal dan siswa masih membutuhkan penyesuaian diri untuk menciptakan suasana belajar yang akrab.

Hasil observasi yang dilakukan oleh peneliti selama melakukan penelitian bercerita pengalaman menggunakan media sortir kartu (sort card) pada siswa kelas X-3 SMAN Lasalimu Selatan, dapat dilihat pada tabel berikut.
Tabel 4.9 Hasil Observasi Siklus I

\begin{tabular}{|c|c|c|c|c|c|}
\hline \multirow{3}{*}{ No } & \multirow{3}{*}{$\begin{array}{c}\text { Aspek } \\
\text { Pengamatan }\end{array}$} & \multicolumn{4}{|c|}{ Sikap dan Keterlibatan } \\
\hline & & \multicolumn{2}{|c|}{$\begin{array}{c}\text { Pertemuan } \\
\text { I }\end{array}$} & \multicolumn{2}{|c|}{$\begin{array}{c}\text { Pertemuan } \\
\text { II }\end{array}$} \\
\hline & & Ya & Tidak & Ya & Tidak \\
\hline 1 & $\begin{array}{l}\text { Antusias siswa } \\
\text { memperhatikan } \\
\text { penjelasan } \\
\text { peneliti }\end{array}$ & 13 & 12 & 15 & 8 \\
\hline 2 & $\begin{array}{l}\text { Antusias siswa } \\
\text { untuk bertanya } \\
\text { dan berkomentar }\end{array}$ & 4 & 21 & 8 & 15 \\
\hline 3 & $\begin{array}{l}\text { Antusias dan } \\
\text { keberanian siswa } \\
\text { untuk bercerita di } \\
\text { depan kelas } \\
\end{array}$ & 2 & 23 & 17 & 6 \\
\hline 4 & $\begin{array}{l}\text { Hubungan antar } \\
\text { teman }\end{array}$ & 19 & 6 & 20 & 3 \\
\hline 5 & $\begin{array}{ll}\text { Sikap } & \text { terhadap } \\
\text { guru } & \end{array}$ & 20 & 5 & 22 & 1 \\
\hline & Jumlah & 58 & 67 & 82 & 33 \\
\hline
\end{tabular}

\section{d. Refleksi Siklus I}

Pembelajaran bercerita pengalaman menggunakan media sortir kartu (sort card) siswa kelas X-3 SMAN 2 Lasalimu Selatan sudah terlaksana satu siklus. Hasil tes siklus I hanya mencapai rerata klasikal persentase $67,44 \%$. Hasil ini memang telah memenuhi persentase keberhasilan di siklus I, namaun hal ini perlu ditingkatkan lagi mengingat persentase yang hendak di capai di siklus II nanti adalah $70 \%$. Jika perbaikan tidak segera dilakukan maka dikhawatirkan di siklus ke dua nanti persentase yang ditargetkan tidak berhasil. Ada beberapa hal yang ditemukan di siklus I ini yang kiranya perlu diperbaiki kembali sebagai persiapan siklus II. Adapun hal-hal tersebut dan cara memerbaikinya antara lain:

1) Pengaruh bahasa daerah yang masih mendominan pada pelafalan siswa saat bercerita. Hal ini memang tidak bisa dirubah sepenuhnya mengingat bahasa ibu adalah bahasa pertama yang dikuasai siswa, namun ala bisa karena biasa. Peneliti bermaksud pada pertemuan pertama siklus II akan menyisihkan waktu sekitar 30 menit untuk mengajari siswasiswa yang kental akan pelafalan bahasa ibu untuk melafalkan huruf-huruf tersebut sesuai pelafalan yang baik dan benar;

2) Rasa gugup, grogi dan malu. Peneliti yakin hal ini terjadi karena tidak adanya keakraban yang 
baik antar peneliti dan siswa sehingga mereka masih menganggap peneliti orang asing yang disegani. Pada pertemuan pertama siklus II peneliti akan berusaha seakrab mungkin dengan siswa sehingga rasa gugup, grogi dan malu dapat dihilangkan ketika bercerita pada pertemuan ke dua;

3) Terbata-batanya siswa dalam menyampaikan cerita. Hal ini terjadi karena kurangnya persiapan yang diberikan kepada siswa dalam menyiapakan pengalaman yang akan mereka ceritakan. Pada pertemuan pertama siklus II, peneliti akan membocorkan tema yang akan dijadikan bahan cerita pada pertemuan ke dua. Hal ini dimaksudkan agar siswa di rumah bisa mencari kira-kira pengalaman apa yang hendak diceritakan.

4) Kurang perhatiannya siswa dalam pembelajaran. Hal ini terjadi akibat peneliti kurang melibatkan siswa dalam kegiatan. Namun, pada pembelajaran siklus II peneliti telah merancang banyak kegiatan yang melibatkan siswa seperti pembelajaran pelafalan huruf yang benar di dalam bahasa Indonesia.

\section{Siklus II}

\section{a. Proses Pembelajaran}

\section{1) Pertemuan Pertama}

Pada pertemuan pertama, pelaksanaan tindakan berlangsung selama $2 \times 45$ menit dan dilaksanakan pada hari Rabu, 18 Januari pukul 09.15 WITA di kelas X-3 SMAN 2 Lasalimu Selatan. Pertemuan ini sama dengan pertemuan pertama siklus I, yakni pada pertemuan ini peneliti belum menyortir kartu karena peneliti masih harus merefleksi siswa mengenai kelemahan yang ditunjukan pada siklus I. Adapun proses pembelajaran pada pertemuan ini adalah:

a) Peneliti membuka pelajaran (apersensi dan presensi);

b) Peneliti menjelaskan kembali tentang tujuan pembelajaran kemampuan bercerita;

c) Peneliti menceritakan pencapaian pada siklus I terhadap siswa menyangkut kelemahan dan cara mengatasinya;

d) Peneliti melatih siswa melafalkan abjad sesuai ejaan bahasa Indonesia yang benar;

e) Peneliti menceritakan sebuah pengalaman dengan cara yang baik dan benar sesuai aspek yang dinilai dalam bercerita pengalaman; d) Peneliti memberikan kesempatan bertanya kepada siswa;

e) Siswa R1 dan R13 bertanya dan dijawab oleh peneliti;

f) Peneliti menyampaikan tema yang menjadi bahan cerita pada pertemuan selanjutnya;

g) Pembelajaran diakhiri dengan doa dan salam.

2) Pertemuan Kedua

Pertemuan kedua ini dilaksnakan pada hari kamis, tanggal 19 Januari 2017 dimulai jam 07.30 WITA di kelas X-3 SMAN Lsalimu Selatan dan berlangsung selama 2X45 menit. Pada pertemuan kali ini, peneliti menggunakan lagi media sortir kartu (sort card). Kartu-kartu yang disortir itu berisi pokok-pokok cerita yang akan dikembangkan oleh siswa secara individu sesuai dengan tema yang diperoleh. Adapun tema yang digunakan pada pertemuan ini adalah "pengalaman liburan". Dengan tema "pengalaman liburan" peneliti membaginya lagi dalam 5 bagian sehingga cerita menjadi variatif. Adapun bagian-bagian tersebut adalah:

a) Pengalaman yang memalukan ketika liburan;

b) Pengalaman yang menjengkelkan ketika liburan;

c) Pengalaman yang membahagiakan ketika liburan;

d) Pengalaman yang menyedihkan ketika liburan;

e) Pengalaman yang lucu ketika liburan;

Pertemuan kedua ini juga menjadi evaluasi dari ujicoba penggunaan media sortir kartu (sort card) di siklus kedua ini. Adapun langkah-langkah yang dilakukan peneliti pada pertemuan ini adalah:

a) Peneliti membuka pelajaran (apersensi dan presensi);

b) Peneliti menjelaskan alur kegiatan yang akan dijalankan bersama-sama;

c) Peneliti menyortir kartu yang berisikan pokok-pokok cerita dengan tema utama "pengalaman liburan" dengan subtema yang berbeda-beda;

d) Peneliti menginstruksikan setiap siswa untuk mencari teman yang mendapatkan subtema yang sama;

e) Peneliti memberikan waktu 15 menit agar siswa berdiskusi tentang pengalaman yang akan diceritakan; 
f) Peneliti meminta siswa secara bergantian untuk menceritakan pengalaman yang telah mereka siapkan;

g) Pelajaran diakhiri dengan berdoa dan salam.

\section{b. Hasil Kemampuan Bercerita Pengalaman Siklus II}

Hasil bercerita pengalaman pada tahap siklus I akan digambarkan pada tabel 4.10 berikut ini.

Tabel 4.10 Hasil Peingkatan Kemampuan Bercerita Pengalaman Siklus II

\begin{tabular}{|c|c|c|c|c|}
\hline Resp & Total Skor & $\begin{array}{c}\text { NILAI AKHIR } \\
\text { iumlah nilai seluruh aspek X100 } \\
\text { Jumlah skor maksimal }\end{array}$ & Kat & Ket \\
\hline R1 & 24 & 80 & B & \\
\hline R2 & 23 & 77 & B & \\
\hline R3 & 20 & 67 & C & \\
\hline R4 & 23 & 77 & B & \\
\hline R5 & 20 & 67 & C & \\
\hline R6 & 27 & 90 & SB & \\
\hline R6 & 23 & 77 & B & \\
\hline R8 & 23 & 77 & B & \\
\hline R9 & 25 & 87 & SB & \\
\hline R10 & 19 & 63 & C & \\
\hline R11 & 23 & 77 & B & \\
\hline R12 & - & - & - & Tidak hadir \\
\hline R13 & 26 & 87 & SB & \\
\hline R14 & 23 & 77 & B & \\
\hline R15 & 25 & 87 & SB & \\
\hline R16 & 24 & 80 & B & \\
\hline R17 & 28 & 93 & SB & \\
\hline R18 & 22 & 73 & B & \\
\hline R19 & 20 & 67 & C & \\
\hline R20 & 19 & 63 & C & \\
\hline R21 & 26 & 87 & SB & \\
\hline R22 & 23 & 77 & B & \\
\hline R23 & 18 & 60 & C & \\
\hline R24 & 19 & 63 & C & \\
\hline R25 & 20 & 67 & C & \\
\hline & & & & \\
\hline
\end{tabular}

Berdasarkan hasil yang telah dipaparkan, maka akan dihitung persentase keberhasihan pada tabel rentang nilai di bawah ini.

Tabel 4.12 Persentase Pencapaian Pada Siklus II

\begin{tabular}{|c|c|c|c|c|c|}
\hline Kat & Rentang nilai & Frekuensi & Bobot skor & Persen (\%) & Persentase keberhasilan \\
\hline Sangat baik & $86-100$ & 6 & 531 & $24 \%$ & $\begin{array}{l}\sum \mathrm{n} \\
\times 100 \%\end{array}$ \\
\hline Baik & $70-85$ & 10 & 772 & $40 \%$ & \\
\hline & $60-69$ & 8 & 517 & $32 \%$ & ${ }^{1.820} \times 100 \%$ \\
\hline Kurang & $0-59$ & - & - & - & $\begin{aligned} & 2.500 \\
= & 72,8 \%\end{aligned}$ \\
\hline \multirow{2}{*}{\multicolumn{2}{|c|}{$\begin{array}{c}\text { Jumlah } \\
\text { Keterangan }\end{array}$}} & 24 & 1.820 & $96 \%$ & \\
\hline & & \multicolumn{4}{|c|}{1 responden $(4 \%)$ tidak hadir } \\
\hline
\end{tabular}


Berdasarkan data pada tabel 4.12 dapat dinyatakan bahwa hasil tes kemampuan bercerita pengalaman pada siklus I siswa kelas X-3 SMAN 2 Lasalimu Selatan, mencapai total nilai 1.820 , dengan persentase $72,8 \%$ yang telah memenuhi persentase keberhasilan di siklus I. Dari jumlah responden 25, terdapat $6(44 \%)$ siswa yang berhasil memperoleh nilai dengan kategori sangat baik dengan rentang nilai 86-100. Selanjutnya siswa yang memperoleh nilai dengan kategori baik terdapat $10(40 \%)$ dengan rentang nilai $70-85$, siswa yang memperoleh nilai dengan kategori cukup terdapat 8 (32\%) dengan rentang nilai 60-69 dan terdapat bahwa $1(4 \%)$ siswa tidak hadir pada pertemuan ini.

Nilai siklus II diperoleh dari penjumlahan skor masing-masing aspek, yaitu pelafalan, intonasi, diksi, ekspresi, kelancaran, dan penegasan cerita. Hasil perolehan nilai untuk masing-masing aspek penilaian bercerita pengalaman menggunakan media sortir kartu (sort card) tercantum dalam tabel-tabel berikut.

Tabel 4.13 Pencapaian Aspek Pelafalan Siklus II

\begin{tabular}{|c|c|c|c|l|c|}
\hline No & Skor & Frekuensi & Bobot Skor & Persentase Keberhasilan & Nilai Rerata \\
\hline 1 & 5 & 0 & 0 & $\frac{\sum \mathrm{n} \text { X100\% NXS }}{\frac{89}{25}}$ \\
2 & 4 & 14 & 56 & 89 & $=3,56$ \\
3 & 3 & 10 & 33 & 125 & kategori cukup \\
4 & 2 & 0 & 0 & & \\
5 & 1 & 0 & 0 & & \\
\hline
\end{tabular}

Berdasarkan tabel 4.13 terdapat bahwa pelafalan siswa kelas X-3 SMAN 2 Lasalimu Selatan saat bercerita mencapai skor rerata 3,58 atau dengan persentase $71,2 \%$. Hal tersebut menandakan bahwa pelafalan siswa saat bercerita masih dikategorikan cukup. Walaupun kategorinya tidak berbah, namun persentase meningkat. Hal ini menandakan bahwa adanya peningkatan dari siklus I. Meskipun permasalahan yang dialami mengenai pelafalan belum dapat teratasi dengan baik.

Tabel 4.14 Pencapaian Aspek Intonasi Siklus II

\begin{tabular}{|c|c|c|c|c|c|}
\hline No & Skor & Frekuensi & Bobot Skor & Persentase Keberhasilan & Nilai Rerata \\
\hline 1 & 5 & 4 & 20 & $\stackrel{\sum \mathrm{n}}{ } \times 100 \% \mathrm{NXS}$ & $\frac{92}{25}$ \\
\hline 2 & 4 & 12 & 48 & & \\
\hline 3 & 3 & 8 & 24 & $\frac{92}{} \times 100 \%$ & $\begin{array}{c}=3,68 \\
\text { Kategori cukup }\end{array}$ \\
\hline 4 & 2 & 0 & 0 & 125 & \\
\hline 5 & 1 & 0 & 0 & $=73,6 \%$ & \\
\hline \multicolumn{2}{|c|}{ Jumlah } & 24 & 92 & & \\
\hline
\end{tabular}


Berdasarkan tabel 4.14 terdapat bahwa intonasi siswa kelas X-3 SMAN 2 Lasalimu Selatan saat bercerita mencapai skor rerata 3,68 atau dengan persentase $73,6 \%$. Hal tersebut menandakan bahwa intonasi siswa saat bercerita masih dikategorikan cukup. Beberapa siswa sudak kelihatan menyampaikan cerita dengan nada yang sesuai. Walaupun memang tidak secara keseluruhan.

Tabel 4.15 Pencapaian Aspek Diksi

Siklus II

\begin{tabular}{|c|c|c|c|c|c|}
\hline No & Skor & Frekuensi & Bobot skor & Persentase keberhasilan & Nilai rerata \\
\hline 1 & 5 & 0 & 0 & $\sum \mathrm{n}$ & $\frac{84}{25}$ \\
\hline 2 & 4 & 12 & 48 & & \\
\hline 3 & 3 & 12 & 36 & ${ }^{84} \times 100 \%$ & $\begin{array}{c}=3,36 \\
\text { Kategori cukup }\end{array}$ \\
\hline 4 & 2 & 0 & 0 & $=672 \%$ & \\
\hline 5 & 1 & 0 & 0 & & \\
\hline \multicolumn{2}{|c|}{ Jumlah } & 24 & 84 & & \\
\hline
\end{tabular}

Berdasarkan tabel 4.15 terdapat bahwa diksi siswa kelas X-3 SMAN 2 Lasalimu Selatan saat bercerita mencapai skor rerata 3,36 atau dengan persentase $67,2 \%$. Hal tersebut menandakan bahwa diksi yang digunakan siswa saat bercerita masih dikategorikan cukup. Meskipun perencanaan siswa lebih banyak dibandingkan dengan penampilan ketika siklus I, namun hal ini tidak terlalu merubah pilihan kata siswa dalam bercerita pengalaman. Meskipun demikian peningkatan tetap ada walaupun dengan persentase yang tidak terlalu kontras.

Tabel 4.16 Pencapaian Aspek Ekspresi Siklus II

\begin{tabular}{|c|c|c|c|c|c|}
\hline No & Skor & Frekuensi & Bobot Skor & Persentase Keberhasilan & Nilai Rerata \\
\hline 1 & 5 & 4 & 20 & $\sum \mathrm{n}$ & $\underline{92}$ \\
\hline 2 & 4 & 12 & 48 & $-\mathrm{X} 100 \% \mathrm{NXS}$ & 25 \\
\hline 3 & 3 & 8 & 24 & $\frac{92}{} \times 100 \%$ & $\begin{array}{c}=3,68 \\
\text { Kategori cukup }\end{array}$ \\
\hline 4 & 2 & 0 & 0 & 125 & \\
\hline 5 & 1 & 0 & 0 & $=73,6 \%$ & \\
\hline \multicolumn{2}{|c|}{ Jumlah } & 24 & 92 & & \\
\hline
\end{tabular}

Berdasarkan tabel 4.16 terdapat bahwa ekspresi siswa kelas X-3 SMAN 2 Lasalimu Selatan saat bercerita mencapai skor rerata 3,68 atau dengan persentase $73,6 \%$. Hal tersebut menandakan bahwa intonasi siswa saat bercerita masih dikategorikan cukup. Walaupun perubahan yang terjadi tidak secara besar, namun ada beberpa siswa yang bisa menampilkan ekspresi yang sempurna sesuai denga cerita yang dibawakan. Ini berarti bahwa refleksi yang dilakukan memberikan manfaat. 
Tabel 4.17 Pencapaian Aspek Kelancaran Siklus II

\begin{tabular}{|c|c|c|c|c|c|}
\hline No & Skor & Frekuensi & Bobot Skor & Persentase Keberhasilan & Nilai Rerata \\
\hline 1 & 5 & 3 & 15 & $\sum^{\sum \mathrm{n}} \times 100 \% \mathrm{NXS}$ & $\frac{80}{25}$ \\
\hline 2 & 4 & 16 & 64 & & \\
\hline 3 & 3 & 4 & 13 & $\frac{92}{2} \times 100 \%$ & $\begin{array}{c}=3,68 \\
\text { Kategori cukup }\end{array}$ \\
\hline 4 & 2 & 0 & 0 & $\begin{array}{l}125 \\
\quad-736 \%\end{array}$ & \\
\hline 5 & 1 & 0 & 0 & & \\
\hline \multicolumn{2}{|c|}{ Jumlah } & 23 & 92 & & \\
\hline
\end{tabular}

Berdasarkan tabel 4.17 terdapat bahwa kelancaran siswa kelas X-3 SMAN 2 Lasalimu Selatan saat bercerita mencapai skor rerata 3,68 atau dengan persentase $73,6 \%$. Hal tersebut menandakan bahwa kelancaran siswa saat bercerita masih dikategorikan cukup.
Tidak ada peningkatan dalam kategori namun persentase yang dicapai pada siklus II ini sedikit meningkat dari siklus I. ini berarti bahwa semua hal akan lebih baik jika berproses dengan baik pula.

Tabel 4.18 Pencapaian Aspek Penegasan Cerita Siklus II

\begin{tabular}{|c|c|c|c|l|c|}
\hline No & Skor & Frekuensi & Bobot Skor & Persentase Keberhasilan & Nilai Rerata \\
\hline 1 & 5 & 3 & 15 & $\frac{\sum \mathrm{n}}{\mathrm{X}} \mathrm{X} 100 \% \mathrm{NXS}$ & $\frac{95}{25}$ \\
2 & 4 & 17 & 68 & 95 & $=3,8$ \\
3 & 3 & 4 & 12 & $\frac{125}{125} \mathrm{X} 100 \%$ & \\
4 & 2 & 0 & 0 & 0 & \\
5 & 1 & 0 & 0 & & \\
\hline \multicolumn{2}{|c|}{ Jumlah } & 24 & 95 & & \\
\hline
\end{tabular}

Berdasarkan tabel 4.18 terdapat bahwa penegasan cerita siswa kelas X-3 SMAN 2 Lasalimu Selatan saat bercerita mencapai skor rerata 3,8 atau dengan persentase $76 \%$. Hal tersebut menandakan bahwa penegasan cerita saat bercerita masih dikategorikan cukup. Aspek menjadi aspek yang paling sedikit penengkatanya dibadingkan dengan peningkatan aspek lainnya. Hal ini dikarenakan pada siklus sebelumnya aspek ini mendapat persentase paling tinggi, jadi jika meningkatpun pada siklus ini menjadi sedikit saja karena aspek yang satu ini telah mendapat nilai yang baik dari siklus sebelumnya.

\section{c. Observasi siklus II}

Observasi yang dilakukan pada siklus II ini sama dengan observasi yang dilakukan pada siklus I. Hasil observasi yang dilakukan oleh peneliti selama melakukan penelitian bercerita pengalaman menggunakan media sortir kartu (sort card) pada siswa kelas X-3 SMAN Lasalimu Selatan, pada siklus kedua banyak perilaku siswa yang meningkat kea rah lebih baik hal tersebut dapat dilihat pada tabel berikut. 
Tabel 4.19 Hasil Observasi Siklus II

\begin{tabular}{|c|l|c|c|c|c|}
\hline \multirow{2}{*}{ No } & \multirow{2}{*}{$\begin{array}{c}\text { Aspek } \\
\text { pengamatan }\end{array}$} & \multicolumn{3}{|c|}{ Sikap dan keterlibatan } \\
\cline { 3 - 6 } 1 & $\begin{array}{l}\text { Iertemuan } \\
\text { I }\end{array}$ & \multicolumn{2}{|c|}{$\begin{array}{c}\text { Pertemuan } \\
\text { II }\end{array}$} \\
\cline { 2 - 6 } & $\begin{array}{l}\text { Yna } \\
\text { memperhatikan } \\
\text { penjelasan } \\
\text { peneliti }\end{array}$ & 21 & Tidak & Ya & Tidak \\
\hline 2 & $\begin{array}{l}\text { Antusias siswa } \\
\text { untuk bertanya } \\
\text { dan } \\
\text { berkomentar }\end{array}$ & 10 & 15 & 11 & 13 \\
\hline 3 & $\begin{array}{l}\text { Antusias dan } \\
\text { keberanian } \\
\text { siswa } \\
\text { untuk bercerita } \\
\text { di depan kelas }\end{array}$ & 15 & 10 & 22 & 2 \\
\hline 4 & $\begin{array}{l}\text { Hubungan antar } \\
\text { teman }\end{array}$ & 20 & 5 & 23 & 1 \\
\hline 5 & $\begin{array}{l}\text { Sikap terhadap } \\
\text { guru }\end{array}$ & 25 & 0 & 24 & 0 \\
\hline \multicolumn{2}{|l}{ Jumlah } & $\mathbf{9 1}$ & $\mathbf{3 4}$ & $\mathbf{1 0 4}$ & $\mathbf{1 6}$ \\
\hline
\end{tabular}

\section{d. Refleksi siklus II}

Siklus II merupakan tindakan memerbaiki kekurangan-kekurangan dalam proses pembelajaran pada siklus I. Proses pembelajaran siswa pada siklus II meningkat dari siklus I.
Kekurangan-kekurangan pada siklus I sudah dapat diatasi pada siklus II, berikut kekurangankekurangan yang ada di siklus I dan meningkat lebih baik pada siklus II.

1. Pengaruh bahasa daerah yang masih mendominan pada pelafalan siswa saat bercerita. Hal ini memang tidak terlalu terlihat lagi pada beberapa siswa;

2. Rasa gugup, grogi dan malu. Rasa-rasa ini sudah dapat teratasi dengan baik, hal ini dapat dilihat pada persentase yang dihasilkan pada aspek intonasi dan ekspresi yang meningkat dari siklus I;

3. Terbata-batanya siswa dalam menyampaikan cerita. Meskipun hal ini masih terjadi pada beberapa siswa, namun ini bukan berarti masalah ini tidak teratasi karena beberapa siswa juga malah semakin baik dalam menyampaikan cerita.

4. Kurang perhatiannya siswa dalam pembelajaran. Proses pembelajaran yang melibatkan siswa menjadikan siswa lebih sibuk dengan dirinya sendiri tanpa memerhatikan ketika pelajaran berlangsung. Dengan melibatkan siswa pada siklus II masalah ini dapat teratasi, meskipun ada beberapa siswa yang gagal fokus, namun ini tetap menjadikan masalah ini teratasi. 